\title{
Indeks Mentzer sebagai Alat Diagnostik Anemia Defisiensi Besi di Sarana Kesehatan dengan Fasilitas Terbatas: Perbandingan Berbagai Nilai Cut Off
}

Teny Tjitra Sari, Nur Aliza, Soedjatmiko

Departemen Ilmu Kesehatan Anak Fakultas Kedokteran Universitas Indonesia/Rumah Sakit Dr. Cipto Mangunkusumo, Jakarta

Latar belakang. Anemia defisiensi besi (ADB) adalah penyebab tersering anemia pada anak kurang dari 5 tahun dan dapat menyebabkan gangguan kognitif, perilaku, dan pertumbuhan yang menetap sehingga diagnosis harus ditegakkan sedini mungkin. Diagnosis ADB ditegakkan dengan pemeriksaan laboratorium yang mahal dan tidak tersedia merata di Indonesia. Untuk itu, penggunaan Indeks Mentzer (IM) merupakan salah satu alat penegakan diagnosis yang mudah.

Tujuan. Mengetahui validitas IM untuk mendiagnosis ADB di daerah dengan fasilitas terbatas, dan mengetahui apakah cut-off point baru diperlukan untuk populasi di Indonesia.

Metode. Penelitian ini merupakan uji diagnostik dengan metode potong lintang. Subjek adalah anak sehat berusia 12-59 bulan yang pucat. Penapisan dilakukan di 27 Posyandu dan 27 PAUD di Kecamatan Jatinegara. Subjek yang memenuhi kriteria inklusi menjalani pemeriksaan darah perifer lengkap, kemudian subjek dengan anemia mikrositik hipokrom diperiksa profil besi dan $C$-reactive protein (CRP). Validitas dinilai dengan membandingkan IM dengan hasil profil besi. Penentuan cut-off point spesifik untuk populasi di Indonesia dilakukan dengan membandingkan sensitivitas, spesifisitas, nilai duga positif(NDP) dan negatif (NDN), rasio kemungkinan positif (RKP), dan rasio kemungkinan negatif (RKN) antara beberapa cut-off points.

Hasil. Penelitian ini mendapatkan 340 subjek dengan klinis pucat, 100 subjek setuju untuk melakukan pemeriksaan laboratorium, dan sisa 45 subjek dengan anemia mikrositik hipokrom. Penelitian ini memberikan sensitivitas 60,5\%, spesifisitas 28,6\%, NDP 82,1\%, NDN 11,8\%, RKP 0,9, dan RKP 1,4. Titik potong baru yang disarankan adalah 10,7 dengan sensitivitas 81,6\% dan NDP 86,1\%. Kesimpulan. Nilai diagnostik IM rendah dengan NDP yang baik untuk diagnosis ADB. Titik potong 10,7 dapat juga digunakan sebagai uji tapis ADB di fasilitas terbatas. Sari Pediatri 2019;21(3):145-51

Kata kunci: anemia defisiensi besi, Indeks Mentzer, fasilitas terbatas

\section{Mentzer Index as Diagnostic Tool for Iron Deficiency Anemia at Limited Health Facility: Comparison of Several Cut Off}

Teny Tjitra Sari, Nur Aliza, Soedjatmiko

Background. Iron deficiency anemia (IDA) is the most common case of anemia for children below 5 years old. IDA results in cognitive delay, behavioral change, and growth delay, therefore, early screening and diagnosis are considered fundamental for better outcome. The current diagnosis of IDA is established on laboratory examination result basis. This examination is considered as too advanced and expensive for underdeveloped healthcare facilities located in remote areas in Indonesia. The use of Mentzer Index (MI) is seen as an easily accessible alternative in establishing IDA diagnosis.

Objective. Aims of this study were to know validity of MI for the diagnosis of IDA in limited facilities, and to decide whether new cut-off point is needed to diagnose IDA in Indonesian population.

Methods. The design of this study is cross-sectional study. The subjects that were involved in the study consisted of children age 12-59 months old, with paleness/pallor. The screening was done in 27 Posyandu and 27 PAUD in Jatinegara area. The subjects who fulfilled inclusion criteria underwent complete blood count examination followed by blood iron analysis and C-reactive protein (CRP). The validity was measured by comparing between MI and blood iron analysis results. The determination of new cut-off point for Indonesian population was performed by comparing sensitivity, specificity, positive predictive value, negative predictive value, positive likelihood ratio, and negative likelihood ratio between some values.

Results. The study yielded 340 subjects with paleness/pallor, only 100 subjects agreed to undergo laboratory examination, and in the end, only 45 subjects were found to have microcytic hypochromic anemia. The study resulted in $60.5 \%$ sensitivity, $28.6 \%$ specificity, $82.1 \%$, positive predictive value, $11.8 \%$, negative predictive value, 0.9 positive likelihood ratio, and $11.8 \%$, negative likelihood ratio for MI in diagnosing IDA. The cut-off point that was recommended for Indonesian population was 10.7 with $81.6 \%$ sensitivity and $86.1 \%$ positive predictive value.

Conclusion. MI has a lower diagnostic value to sensitively and specifically diagnose IDA. The recommended cut-off point for Indonesian population to screen for IDA in limited facilities is 10.7. Sari Pediatri 2019;21(3):145-51

Keywords: iron deficiency anemia, Mentzer Index, limited facilities

Alamat korespondensi: Teny Tjitra Sari. Departemen Ilmu Kesehatan Anak Fakultas Kedokteran Universitas Indonesia / Rumah Sakit Dr. Cipto Mangunkusumo, Jakarta. Email: t_tjitrasari@yahoo.com 
Teny Tjitra Sari dkk: Indeks Mentzer sebagai alat diagnostik anemia defisiensi besi di sarana kesehatan dengan fasilitas terbatas

A

nemia dapat diartikan sebagai berkurangnya kadar hemoglobin $(\mathrm{Hb})$, hematokrit $(\mathrm{Ht})$ atau jumlah sel darah merah per milimeter kubik. ${ }^{1}$ World Health Organization Anemia (WHO) menggunakan kadar $\mathrm{Hb}$ sebagai tolak ukur anemia dan dibedakan berdasarkan usia. Anemia merupakan masalah global yang dapat menyerang berbagai usia, baik di negara maju maupun berkembang. Prevalensi anemia secara global untuk anak usia pra-sekolah adalah 47,4\% dengan populasi terbanyak di Asia, Afrika, dan Amerika Selatan. Jumlah kasus anemia terbanyak didapatkan di Asia dengan prevalensi $58 \% .^{2}$ Indonesia sebagai salah satu negara terbesar di Asia Tenggara juga menghadapi masalah yang sama. Riset Kesehatan Dasar (Riskesdas) 2013 melaporkan proporsi anemia di Indonesia untuk anak pra-sekolah adalah 28,1\%. ${ }^{3}$ Anemia adalah suatu kelainan yang dapat ditimbulkan oleh berbagai penyebab, baik masalah nutrisi (defisiensi vitamin atau mineral) atau non-nutrisi (infeksi, penyakit kronik) dan dapat timbul bersamaan. Lebih dari 50\% anemia diperkirakan akibat defisiensi besi. ${ }^{4-6}$ Sekartini $\mathrm{dkk}^{7}$ dalam penelitiannya di empat Pusat Kesehatan Masyarakat (Puskesmas) kecamatan di Jakarta Timur mendapatkan 38,2\% bayi 4-12 bulan mengalami anemia dan $71,4 \%$ bayi tersebut menderita anemia defisiensi besi (ADB). Hal ini dapat terjadi akibat asupan zat besi yang kurang, absorpsi zat besi yang rendah atau pertumbuhan yang cepat. ${ }^{4,5}$

Anemia defisiensi besi dapat memengaruhi pertumbuhan dan perkembangan anak seumur hidup karena menyebabkan gangguan kognitif, perilaku, dan pertumbuhan pada anak. ${ }^{5,6}$ Kadar $\mathrm{Hb}$ yang rendah tidak hanya ditemukan pada $\mathrm{ADB}$, tetapi juga penyakit-penyakit lain, seperti keracunan timbal, thalassemia, anemia sideroblastik, dan anemia akibat inflamasi. Indonesia sebagai bagian dari negara sabuk Thalassemia memiliki prevalens thalassemia yang cukup tinggi, yaitu sekitar $2-11 \%$ sehingga sangat penting untuk membedakan ADB dari thalassemia akibat adanya perbedaan tata laksana dan prognosis. Anemia defisiensi besi dengan anemia mikrositik lainnya dapat dibedakan berdasarkan anamnesis dan pemeriksaan klinis. ${ }^{8-9}$

Diagnosis ADB kadang sulit ditegakkan berdasarkan gejala dan pemeriksaan fisik saja karena tidak spesifik. Pada bayi dan anak prasekolah, ADB sering tanpa keluhan, sedangkan gejala yang khas seperti koilonikia atau glositis jarang ditemukan dalam praktek sehari- hari. Untuk itu diperlukan pemeriksaan laboratorium dalam penegakan diagnosis. ${ }^{8}$ Pemeriksaan baku emas untuk mendiagnosis $\mathrm{ADB}$ adalah pewarnaan sumsum tulang, tetapi pemeriksaan ini jarang dikerjakan karena invasif. Pemeriksaan lain untuk diagnosis pasti ADB adalah mengukur kadar protein pengikat zat besi baik di serum atau sel darah. Pemeriksaan ini mahal dan belum tersedia di setiap fasilitas kesehatan. Pemeriksaan lain yang sering dikerjakan adalah mencari bukti kurangnya kadar zat besi dengan penurunan kadar $\mathrm{Hb}^{8}{ }^{8,10}$ Pemeriksaan kadar $\mathrm{Hb}$ paling sering digunakan untuk uji tapis $\mathrm{ADB}$ namun pemeriksaan ini memililiki kadar sensitivitas dan spesifisitas yang rendah. White ${ }^{11}$ meneliti sensitivitas kadar $\mathrm{Hb}$ untuk mendiagnosis ADB hanya 30\% dengan nilai batas $\mathrm{Hb}$ kurang dari $11 \mathrm{mg} / \mathrm{dL}$ [interval kepercayaan (IK) 95\% 24-52\%] dan $15 \%$ dengan nilai batas $\mathrm{Hb} 10,7 \mathrm{mg} / \mathrm{dL}$ ( IK 95\% $7-22 \%)$.

Indeks Mentzer (IM) adalah salah satu formula indeks diskriminasi yang dikembangkan sebagai uji tapis trait thalassemia untuk membedakannya dari anemia mikrositik hipokrom lain khususnya ADB dengan menghitung volume rata-rata sel atau mean corpuscular volume (MCV) dibagi dengan jumlah eritrosit. Nilai yang lebih dari 13 prediktor untuk ADB sedangkan kurang dari 13 prediktor untuk trait thalassemia. Hasil dari penelitian ini dapat membuktikan apakah cut-off point 13 memiliki nilai diagnostik yang tinggi untuk penegakan diagnosis ADB di Indonesia. IM telah terbukti memiliki reliabilitas yang baik untuk membedakan trait thalassemia. ${ }^{12}$ Vehapoglu $\mathrm{dkk}^{13}$ menemukan bahwa IM memiliki sensitivitas $98,7 \%$, spesifisitas $82,3 \%$ dan indeks Youdan $81 \%$ untuk uji tapis thalassemia, tertinggi dibandingkan indeks diskriminasi lain. Alam dkk ${ }^{12}$ telah menggunakan IM untuk diagnosis ADB anak usia sekolah dengan hasil yang baik yaitu sensitivitas $93 \%$ dan spesifisitas $84 \%$. Pemeriksaan IM yang mudah dapat dilakukan di Puskesmas tingkat kecamatan yang telah memiliki mesin analisis hematologi elektronik. Penelitian ini dilakukan di Pusat Pelayanan Terpadu (Posyandu) yang merupakan perpanjangan tangan Puskesmas untuk meningkatkan kesehatan ibu dan anak dan di sekolah-sekolah Pendidikan Anak Usia Dini (PAUD). Penelitian ini bertujuan untuk mengetahui validitas IM untuk mendiagnosis ADB di daerah dengan fasilitas terbatas, dan mengetahui apakah cut-off point baru diperlukan untuk populasi di Indonesia. 
Teny Tjitra Sari dkk: Indeks Mentzer sebagai alat diagnostik anemia defisiensi besi di sarana kesehatan dengan fasilitas terbatas

\section{Metode}

Penelitian dilakukan dengan desain studi potong lintang. Hasil IM dari pemeriksaan darah perifer dibandingkan dengan hasil pemeriksaan darah untuk ADB berdasarkan kriteria WHO yaitu $\mathrm{Hb}$, feritin, Serum Iron (SI), Total Iron Binding Capacity (TIBC), dan saturasi transferin. Penelitian dilakukan di 27 Posyandu dan PAUD di 6 kelurahan di wilayah kerja Puskesmas Kecamatan Jatinegara, Jakarta Timur.

Sampel adalah subjek dengan anemia mikrositik hipokrom yang menjalani penapisan ADB di Posyandu dan PAUD yang memenuhi kriteria inklusi dan kriteria eksklusi. Kriterian inklusi penelitian adalah anak usia 12-59 bulan yang tampak pucat berdasarkan pemeriksaan klinis yang dilakukan oleh peneliti, didukung dengan hasil pemeriksaan penunjang yang menyatakan anemia mikrositik hipokrom pada pemeriksaan darah tepi. Pasien dieksklusi bila dijumpai gizi buruk, infeksi akut, penyakit kronik, riwayat transfusi dan pemberian obat suplementasi zat besi. Pemilihan sampel dengan metode konsekutif. Setelah mendapatkan persetujuan dari orang tua, subjek dilakukan pemeriksaan fisik lengkap dan antropometri. Subjek diambil sebanyak 5 $\mathrm{ml}$ yang dipisahkan menjadi $1 \mathrm{ml}$ untuk pemeriksaan DPL sedangkan $4 \mathrm{ml}$ untuk pemeriksaan profil besi dan $C$-reactive protein (CRP). Seluruh sampel darah diperiksa di laboratorium patologi klinik RSUPN Cipto Mangunkusumo (RSCM), menggunakan mesin analisis hematologi elektronik Sysmex XN2000 untuk pemeriksaan DPL dan Cobas C501 untuk pemeriksaan profil besi dan CRP. Sampel yang telah diambil disimpan dalam coolbox, suhu dijaga $1-4^{\circ} \mathrm{C}$ kemudian dibawa ke laboratorium RSCM dalam 4-6 jam.

Diagnosis ADB ditegakkan sesuai kriteria WHO dimana terdapat $\mathrm{Hb}$ kurang dari $11 \mathrm{~g} / \mathrm{dL}$ disertai dua dari tiga kriteria yaitu kadar Serum Iron (SI) dari 50 $\mathrm{ug} / \mathrm{dL}$, feritin $<12 \mathrm{ng} / \mathrm{mL}$, TIBC $>410 \mathrm{ug} / \mathrm{dL}$ dan saturasi transferin kurang dari $15 \% .^{6}$ Penghitungan Indeks Mentzer (IM) dilakukan pada subjek dengan anemia mikrositik hipokrom dan dibandingkan dengan hasil pemeriksaan profil besi dalam tabel 2x2 yang kemudian dirangkum berdasarkan angka titik potongnya. Perhitungan mencakup sensitivitas, spesifisitas, NDP, NDN, RKP, dan RKN serta nilai AUC dan titik potong baru. Analisis statistik dilakukan dengan SPSS 20.0.

\section{Hasil}

Penapisan dilakukan terhadap 1273 subjek usia 1259 bulan, dimana sebagian besar subjek berusia $>36$ bulan melaksanakan penapisan di PAUD, dan pasien $\leq 36$ bulan melaksanakan penapisan di Posyandu. Dari 1273 subjek ditemukan sebanyak 340 subjek memenuhi kriteria pucat, namun hanya 100 subjek yang dilakukan pemeriksaan laboratorium (Gambar 1).

Pemeriksaan darah perifer lengkap menghasilkan 49 subjek dengan kriteria anemia mikrositik hipokrom Peningkatan CRP ditemukan pada 7 subjek, sebanyak 4 subjek dieksklusi karena hasil feritin yang meningkat, dan 3 subjek tetap dimasukkan karena memenuhi kriteria ADB. Total subjek dengan ADB berjumlah 38 , sedangkan subjek non-ADB berjumlah 7 orang. Subjek non-ADB adalah subjek yang menderita anemia penyakit kronik, dan thalassemia (Gambar 1).

Jumlah subjek dengan ADB berdasarkan pemeriksaan baku emas laboratorium adalah 38 subjek yang terdiri dari 23 subjek dengan nilai $\mathrm{IM}>13$ dan 15 subjek dengan nilai IM $\leq 13$. Subjek dengan $\mathrm{ADB}$ diberikan terapi zat besi $4-5 \mathrm{mg} / \mathrm{kg} / \mathrm{hari}$ dan surat rujukan ke Puskesmas untuk pengobatan lebih lanjut.

Jumlah subjek dengan anemia non-ADB adalah 7 subjek yang terdiri dari 5 subjek dengan IM $>13$ dan 2 subjek dengan $\mathrm{IM} \leq 13$.

Karakteristik 45 subjek penelitian dapat dilihat pada Tabel 1. Rerata usia subjek penelitian adalah 31,4 bulan dengan IK 95\% adalah 27,2\%-33,2\%. Terdapat 10 subjek $(22,2 \%)$ berusia antara $12-24$ bulan dan sisanya berusia antara 25-59 bulan. Distribusi jenis kelamin di kedua kelompok seimbang antara kelompok lelaki dan perempuan. Terdapat 1 subjek $(2,2 \%)$ dengan gizi lebih dan 11 subjek $(24,5 \%)$ dengan gizi kurang, sisanya memiliki gizi baik (Tabel $1)$.

Median dan rerata hasil pemeriksaan laboratorium dapat dilihat pada Tabel 2. Kadar Hb, jumlah RBC, dan MCV tidak ditemukan perbedaan yang bermakna antara kelompok $\mathrm{ADB}$ dan non-ADB, sedangkan pada profil besi terdapat perbedaan bermakna (Tabel 2).

Tabel 3 memperlihatkan perbandingan antara cut-off point Indeks Mentzer yang digunakan secara universal (13) dengan cut-off point lain (10,7 dan 14,3) untuk mencari sensitivitas dan spesifisitas terbaik. Tabel 3 memperlihatkan IM memiliki rerata sensitivitas $62,9 \%$, spesifisitas $28,6 \%$ dengan NDP (positive predictive value) dan NDN (negative predictive value) 


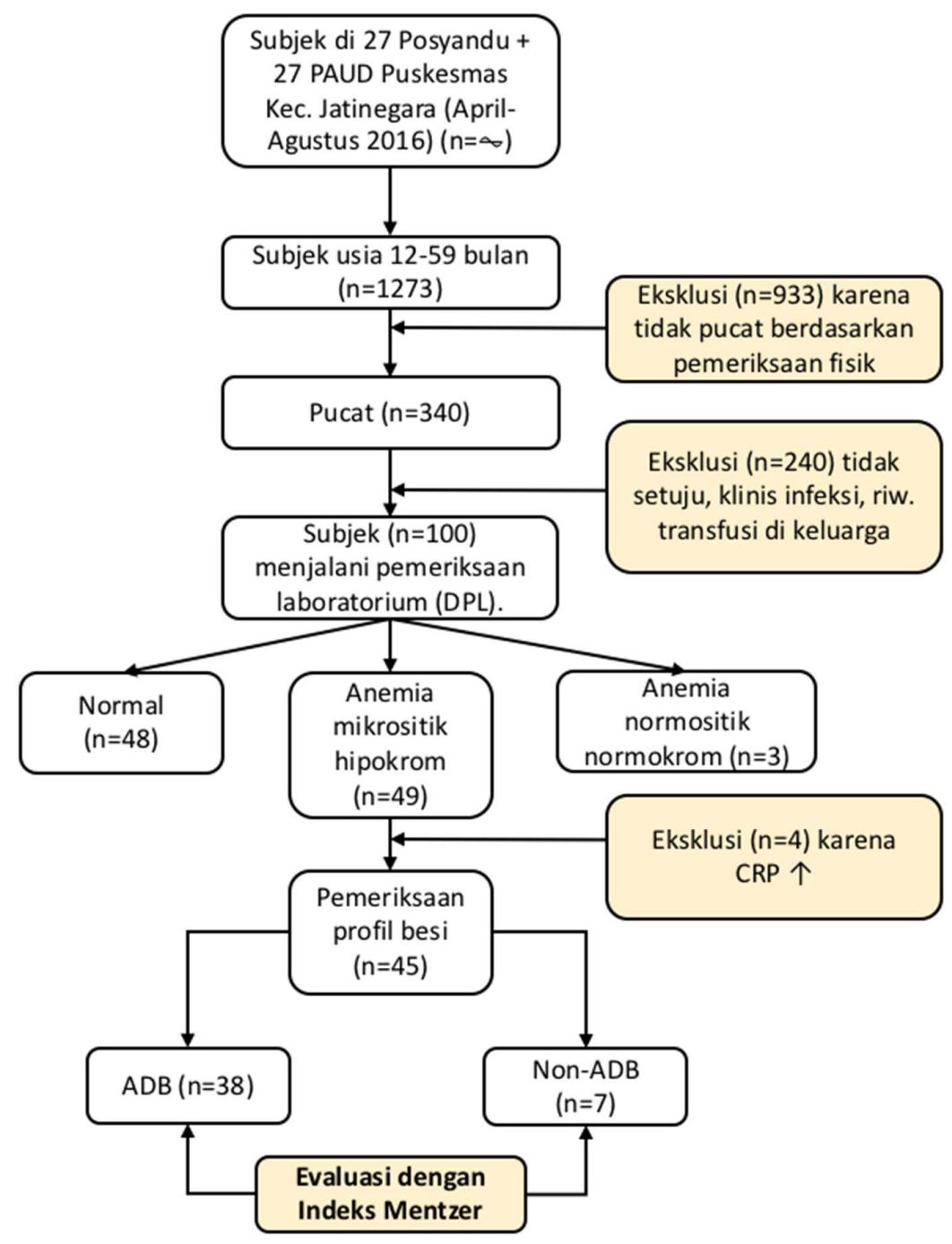

Gambar 1. Seleksi subjek penelitian

Tabel 1. Karakteristik dasar subjek penelitian

\begin{tabular}{lcc}
\hline Karakteristik & $\mathrm{N}$ & Persentase (\%) \\
\hline Jenis kelamin & & \\
Laki-laki & 23 & 51,1 \\
Perempuan & 22 & 48,9 \\
Kelompok umur (bulan) & & \\
12-24 & 10 & 22,2 \\
$25-59$ & 35 & 77,8 \\
Status nutrisi & & \\
Gizi lebih & 1 & 2,2 \\
Gizi baik & 33 & 73,3 \\
Gizi kurang & 11 & 24,5 \\
\hline
\end{tabular}


Teny Tjitra Sari dkk: Indeks Mentzer sebagai alat diagnostik anemia defisiensi besi di sarana kesehatan dengan fasilitas terbatas

Tabel 3. Perbandingan setiap cut-off point pada IM

\begin{tabular}{lccc}
\hline Variabel & IM pada 10,7 & IM pada 13 & IM pada 14,3 \\
\hline Sensitivitas & $81,6 \%(65,5-93)$ & $60,5 \%(43,4-75,9)$ & $26,32 \%(13,4-43,1)$ \\
Spesifisitas & $28,6 \%(3,7-71)$ & $28,6 \%(3,7-70,9)$ & $28,57 \%(3,7-70,9)$ \\
NDP (positive predictive valuei) & $86,1 \%(79,1-91)$ & $82,1 \%(72,9-88,7)$ & $66,7 \%(49,6-80,3)$ \\
NDN (negative predictive value) & $22,2 \%(6,9-52,4)$ & $11,8 \%(3,7-31,5)$ & $6,7 \%(2,1-18,9)$ \\
RKP(positive likelihood ratio) & $1,1(0,7-1,9)$ & $0,9(0,5-1,5)$ & $0,4(0,2-0,8)$ \\
RKN (negative likelihood ratio) & $0,6(0,2 ; 2,3)$ & $1,4(0,4-4,8)$ & $2,4(0,8-8,5)$ \\
\hline
\end{tabular}

Tabel 2. Kadar hemoglobin, jumlah eritrosit, MCV, dan profil besi berdasarkan kelompok ADB dan Non-ADB

\begin{tabular}{lccccc}
\hline \multirow{2}{*}{ Variabel } & \multicolumn{2}{c}{ ADB } & \multicolumn{2}{c}{ Non-ADB } & \multirow{2}{*}{ p } \\
\cline { 2 - 4 } & Nilai & $\begin{array}{c}\text { Min-Max* } \\
\text { IK 95\% }\end{array}$ & Nilai & $\begin{array}{c}\text { Min-Max* } \\
\text { IK 95\% }\end{array}$ & \\
\hline Hemoglobin $(\mathrm{g} / \mathrm{dL})^{*}$ & 10,2 & $7,5-10,9$ & 10,4 & $8-10,9$ & 0,481 \\
Jumlah RBC $\left(10^{6} / \mu \mathrm{l}\right)$ & $4,9^{*}$ & $4,3-6,4$ & 4,8 & 4,$4 ; 5,2$ & 0,379 \\
MCV $(\mathrm{fL})$ & 63,9 & $62 ; 66$ & 65,9 & 58,$1 ; 73,7$ & 0,468 \\
Serum iron $(\mu \mathrm{g} / \mathrm{ml})$ & 27,9 & 24,$6 ; 31,4$ & 81,6 & 57,$8 ; 105,4$ & 0,000 \\
TIBC $(\mu \mathrm{g} / \mathrm{ml})$ & 425,1 & 403,$2 ; 447$ & 325,9 & 294,$1 ; 357,6$ & 0,000 \\
Saturasi transferin $(\%)$ & 6,9 & 5,$9 ; 7,9$ & 25 & 18,$2 ; 31,8$ & 0,000 \\
Feritin $(\mu \mathrm{g} / \mathrm{ml})$ & 7,5 & 6,$3 ; 8,6$ & 32,9 & 14,$5 ; 51,4$ & 0,000 \\
\hline
\end{tabular}

Keterangan: Variabel numerik yang berdistribusi normal disajikan dalam rerata, sedangkan yang tidak normal $\left({ }^{*}\right)$ disajikan dalam median (rentang)

81,5\% dan 13,3\%, RKP (positive likelihood ratio) dan RKN (negative likelihood ratio). Di antara tiga angka diagnostik yang diteliti, IM pada 10,7 memiliki sensitivitas yang lebih tinggi $(81,6 \%)$, spesifisitas yang relatif sama $(28.6 \%)$, NDP paling tinggi $(86,1 \%)$, NDN paling tinggi $(22,2 \%)$, RKP paling tinggi $(1,1)$, dan RKN paling rendah $(0,6)$, bila dibandingkan dengan angka diagnostik yang lebih tinggi pada IM 13 dan 14,3 (Tabel 3).

\section{Pembahasan}

Penelitian dilakukan di 27 Posyandu terhadap 100 subjek sehingga data yang dikumpulkan merupakan data primer. Subjek menjalani pemeriksaan laboratorium berupa pemeriksaan darah perifer lengkap, profil besi, dan CRP. Seluruh alat analisis di laboratorium RSCM menjalani validasi rutin sehingga hasil yang diberikan dapat dipercaya. Limitasi yang ditemui pada penelitian ini adalah tidak dilakukannya pemeriksaan gambaran darah tepi dan analisis Hb yang berguna untuk penelusuran etiologi lain pada kasus anemia mikrositik hipokrom. Selain itu, subjek yang dieksklusi cukup besar karena subjek mengundurkan diri. Subjek yang mengundurkan diri umumnya berusia di bawah 24 bulan sehingga sebaran usia tidak merata. Jumlah subjek pucat dengan pemeriksaan darah yang normal mencapai 48\% dengan median $\mathrm{Hb} 11,9 \mathrm{~g} / \mathrm{dL}$, rerata MCV 72,67 pg, dan rerata jumlah eritrosit 4,9x10\% $\mu$ l. Sebanyak 19 subjek memiliki morfologi mikrositik hipokrom tetapi tidak dilakukan pemeriksaan profil besi karena tidak memenuhi kriteria anemia, sehingga tidak diketahui status besinya.

Penelitian ini menemukan $84,4 \%$ dari subjek anemia mikrositik hipokrom adalah ADB. Hal ini disebabkan karena perbedaan kelompok umur dan metode penelitian. Penelitian ini menetapkan ADB tidak hanya berdasarkan penurunan kadar feritin, tapi disertai dengan penurunan kadar $\mathrm{Hb}$, serum iron, saturasi transferin dan peningkatan TIBC sehingga memenuhi kriteria ADB. Prevalensi ADB lebih tinggi pada anak di bawah lima tahun karena asupan zat besi yang tidak adekuat dikombinasi dengan adanya pertumbuhan yang cepat khususnya di dua tahun pertama kehidupan. ${ }^{14,15}$

Formula IM adalah nilai MCV dibagi dengan jumlah eritrosit (RBC) sehingga secara umum keadaan yang memengaruhi nilai MCV dan RBC akan mengurangi validitas perhitungan MCV/RBC 
Teny Tjitra Sari dkk: Indeks Mentzer sebagai alat diagnostik anemia defisiensi besi di sarana kesehatan dengan fasilitas terbatas

sebagai alat diagnostik. ${ }^{16}$ Sensitivitas IM yang dicapai pada penelitian ini adalah $60,5 \%$ dengan spesifisitas $28,6 \%$. Hal ini berarti IM dengan nilai standar tidak memenuhi kriteria alat uji tapis yang baik yaitu memiliki sensitivitas lebih dari $80 \%$ walaupun dengan spesifisitas yang rendah. ${ }^{17}$ Hasil ini berbeda bila dibandingkan dengan penelitian Alam dkk ${ }^{12}$ yang melaporkan IM merupakan alat uji tapis yang baik dengan sensitivitas $93 \%$ dan spesifisitas $84 \%$. Hal ini dapat disebabkan akibat perbedaan populasi sampel dan metode penelitian yang digunakan.

Pada ADB, nilai MCV dan jumlah eritrosit diharapkan rendah sehingga nilai IM yang diperoleh tinggi. Thalassemia sebagai diagnosis banding tersering untuk ADB juga memiliki gambaran anemia mikrositik hipokrom, namun memiliki jumlah eritrosit yang meningkat sebagai kompensasi keadaan hipoksia kronik. ${ }^{14,18-21}$ Akibatnya, jika IM diterapkan pada penderita thalassemia maka akan diperoleh nilai yang rendah. Thalassemia minor atau karier thalassemia sering kali asimtomatik namun masih memiliki karakteristik anemia mikrositik hipokrom dan peningkatan eritrosit.

Sebanyak 15 subjek (37\%) pada penelitian ini memiliki jumlah eritrosit yang lebih besar dari $5 \times 10^{6} \%$ $\mu$ pada kelompok ADB dan 13 subjek diantaranya (86.7\%) dengan IM kurang dari 13. Pada penelitian ini kemungkinan thalassemia pada subjek belum dikonfirmasi dengan pemeriksaan laboratorium sehingga belum dapat disingkirkan. Eksklusi dilakukan berdasarkan riwayat thalassemia dan transfusi berulang dalam keluarga serta tidak didapatkannya organomegali atau wajah Cooley. Pemeriksaan indeks eritrosit saja tidak dapat membedakan antara jenis thalassemia dan ADB. ${ }^{22}$ Perlu pemeriksaan yang lebih lanjut untuk menegakkan diagnosis trait thalassemia sebagai penyebab rendahnya IM belum dapat disingkirkan.

Mentzer ${ }^{16}$ melakukan analisis terpisah untuk subjek yang mengidap kedua penyakit. Subjek dengan anemia memberikan hasil sugestif terhadap ADB sedangkan jika kadar $\mathrm{Hb}$ normal memberikan hasil sugestif thalassemia. Amid $\mathrm{dkk}^{23}$ melaporkan terdapat 15 subjek dengan IM $<13$ dan 13, di antaranya dengan jumlah eritrosit meningkat, tetapi belum dievaluasi ke arah thalassemia sehingga tidak dapat disimpulkan apakah IM yang rendah akibat komorbid dengan thalassemia trait sehingga validitas berkurang.

Penelitian ini memberikan NDP yang cukup baik, yaitu $82,1 \%$. Hal ini berarti kemungkinan positif pada suatu hasil yang positif adalah $82,1 \%$. Nilai ini harus relevan dengan NDN. Hasil NDN pada penelitian ini adalah 13,33\% yang berarti kemungkinan negatif pada hasil yang negatif hanya $13,33 \%$. Nilai ini tidak cukup baik karena kemungkinan negatif semu besar. Nilai RKP dan RKN pada penelitian ini juga tidak cukup baik. Nilai RKP adalah 0,88 sedangkan nilai RKP yang baik adalah di atas 10 . Nilai RKN yang dicapai adalah 1,3 , sedangkan nilai RKN yang baik adalah di bawah $0,1 .{ }^{24}$ Perhitungan uji diagnostik MCV/RBC dengan nilai titik potong yang baru memberikan hasil diagnostik yang lebih rendah. Nilai duga positif dan negatif yang memiliki arti yang lebih penting untuk klinisi juga menurun. Hal ini menunjukkan nilai titik potong yang baru tidak cukup baik untuk digunakan dalam mendiagnosis ADB. Tabel 3 menunjukkan perhitungan uji diagnostik dengan titik potong 10.7 memberikan nilai diagnostik yang cukup baik dengan sensitivitas 81,6\%, dan NDP 86,1\%. Hasil ini memberikan nilai diagnostik yang lebih baik jika dibandingkan dengan menggunakan IM dengan titik potong 13. Nilai duga negatif yang meningkat dan rasio kemungkinan negatif yang menurun menunjukkan kemungkinan negatif semu berkurang jika menggunakan titik potong ini. Nilai spesifisitas dan NDN yang rendah membuat nilai ini hanya baik untuk uji tapis.

Sebagai kesimpulan, nilai MCV/RBC dengan titik potong 10,7 dapat digunakan untuk uji tapis $\mathrm{ADB}$ di sarana fasilitas terbatas, sedangkan IM dengan titik potong 13 memiliki nilai diagnostik yang rendah untuk ADB. Nilai MCV/RBC >10,7 dapat mulai diberikan terapi zat besi untuk $\mathrm{ADB}$ dengan memantau efek terapi.

\section{Daftar pustaka}

1. Lanzkowsky P. Classification and diagnosis of anemia during childhood. Dalam: Lanzkowsky manual of pediatric hematology and oncology. Edisi ke-4. London: Elsevier;2005.h.31-46.

2. McLean E, Cogswell M, Egli I, Wojdyla D, de Benoist B. Worldwide prevalence of anemia. Dalam: Badham J, Zimmermann MB, Kraemer K, penyunting. The guidebook of nutritional anemia. Geneva: WHO Press;2007.h.11-2.

3. Badan penelitian dan pengembangan kesehatan. Riset kesehatan dasar 2013. Jakarta: Kementrian Kesehatan RI; 2013.

4. Clark SF. Iron deficiency anemia. Nutr Clin Pract 
Teny Tjitra Sari dkk: Indeks Mentzer sebagai alat diagnostik anemia defisiensi besi di sarana kesehatan dengan fasilitas terbatas

2008;23:128-41.

5. Gunadi D, Lubis B, Rosdiana N. Terapi dan suplementasi besi pada anak. Sari Pediatri 2009;11:207-22.

6. World Health Organization. Iron deficiency anaemia: assessment, prevention and control - a guide for programme managers. Geneva: WHO Press; 2001.

7. Sekartini R, Soedjatmiko, Wawolumaya C, Yuniar I, Dewi R, Nycane, dkk. Prevalens anemia defisiensi besi pada bayi usia 4-12 bulan di Kecamatan Matraman dan sekitarnya, Jakarta Timur. Sari Pediatri 2005;7:2-8.

8. Cook JD. Diagnosis and management of iron deficiency anemia. Clin Haematol 2005;18;319-32.

9. Eleftheriou A, Angastiniotis M. A report on thalassemia for the Association of South East Asian Nations. Thalasemia International Federation; 2013.

10. Submaraniam G, Girish M. Iron deficiency anemia in children. Indian J Pediatr 2015;10:1643-9.

11. White KC. Anemia is a poor predictor of iron deficiency among toddlers in United States. Pediatrics 2005;115:315-20.

12. Alam SLS, Purnamasari R, Bahar E, Rahadiyanto KY. Mentzer index as a screening tool for iron deficiency anemia in 6-12 year-old children. Paediatr Indones 2014;54:294-8.

13. Vehapoglu A, Ozgurhan G, Demir AD, Uzuner S, Nursoy MA, Turkemen S, Kacan A. Hematological indices for differential diagnosis of $\beta$-thalassemia trait and iron deficiency anemia. Anemia 2014;2014:1-7.

14. Ozdemir N. Iron deficiency anemia from diagnosis to treatment in children. Turk Ped Ars 2015;50:11-9.

15. Sandjaja S, Budiman B, Harahap H, Ernawati F, Soekatri
M, Widodo Y dkk. Food consumption and nutritional and biochemical status of 0.5 - 12-year-old Indonesia children : the SEANUTS study. Br J Nutr 2013;110:11-20.

16. Mentzer WC, Jr. Differrentiation of iron deficiency from thalassemia trait. Lancet 1973;1:882.

17. Puspogenoro HD, Wirya IGNW, Pudjiadi AH, Bisanto J, Zulkarnain SZ. Uji diagnostik. Dalam: Sastroasmoro S, Ismael S, penyunting Dasar-dasar metodologi penelitian klinis. Edisi ke5. Jakarta: Sagung Seto;2014.h.219-42.

18. Windgassen EB, Funtowicz L, Lunford TN, Harris LA, Mulvagh SL. C-reactive protein and high-sensitivity C-reactive protein: an update for clinicians. Postgrad Med 2011;123:114-9.

19. Pasricha SR, Black J, Muthayya S, Shet A, Bhat V, Nagaraj S, $\mathrm{dkk}$. Determinants of anemia among young children in rural India. Pediatrics 2010;26:140-9.

20. Chuan S, Jiang YM, Shi H, Liu JH, Zhou WJ, Dai QK. Evaluation of indices in differentiation between iron deficiency anemia and $\beta$-thalassemia trait for Chinese children. J Pediatr Hematol Oncol 2010;32:218-22.

21. Miller JL. Iron deficiency anemia: a common and curable disease. Cold Spring Harb Perspect Med 2013;3:1-13.

22. Gorakshakar AC, Colah RB. Is RBC discrimination index suitable for differentiating between $\alpha$ - and $\beta$-thalassemias? Indian J Hum Genet 2011;17:115-6.

23. Amid A, Haghi-Ashtiani B, Kirby-Allen M, Haghi Asthiani MT. Screening for thalassemia carriers in population with high rate of IDA. Hemoglobin 2015:39;141-3.

24. Dahlan, MS. Analisis penelitian diagnostik. Dalam: Penelitian diagnostik. Jakarta: Salemba Medika:2009.h.19-30. 